\title{
WEST AFRICA: \\ Cooperative Institutionalization of Conflict Prevention Mechanisms in Regional Subsystems
}

\author{
Reuben J. B. LEWIS
}

\begin{abstract}
Conflict prevention projects require concerted efforts by institutions and groups towards its operationalization. The multi-dimensional and multi-faceted agendas of preventive action, as well as the process-based nature of its organization and implementation, make its outcomes unpredictable and hard to evaluate. In a regional subsystem such as West Africa for prevention mechanisms to gain solid footing they must be embedded within institutions that serve as pillars and carriers working towards its institutionalization. In this regard, therefore, this article explores a concept of cooperative institutionalization in regional subsystem as an applicable method for organization and implementation of conflict prevention mechanisms across communities in the sub-region. The paper explains existing institutional capacities for transnational implementation of conflict prevention mechanisms and responds to a critical question of how can institutional cooperation and partnership between sub-regional, state, non-state and local actors help to institutionalize conflict prevention; and how and in what way institutions converge in taking action to respond to conflict risk factors in the sub-region?
\end{abstract}

Keywords: Cooperative institutionalization, ECOWAS, conflict prevention, West Africa.

Reuben J. B. LEWIS

Lecturer, Department of Peace and

Conflict Studies, Fourah Bay College,

University of Sierra Leone

E-mail: reubenlewis2005@yahoo.com

Conflict Studies Quarterly

Issue 30 , January 2020, pp. 55-71

DOI:10.24193/csq.30.3

Published First Online: 05/01/2020

\section{Introduction}

The idea and practice of conflict prevention are considered to be more than extremely controversial in all kinds of settings. On the academic and research domain, there are disagreements over its meaning, scope and conceptual composition. Whilst for practitioners in the peacebuilding community, they view it as broad, unattractive and hard to evaluate. Both scholars and practitioners 
disagree over its conceptual scope as well as its organizational arrangements. However, the practice of conflict prevention is organized around different programs and processes that are divided into direct or operational and structural or deep prevention. The former deals with immediate actions that respond to risk of impending conflict such as mediation, early warning, military deployment, dialogue, reconciliation, etc.; whilst the latter deals with long term responses that involve good governance and development initiatives (United Nations Report, 2001).

In recent years, the idea of systematic prevention has emerged which aims to tackle conflict risk factors and human security concerns such as transnational terrorism, arms proliferation, drug trafficking, health epidemic, cross border armed criminality, climate change etc., which affect communities across countries (United Nations, 2005, United Nations Report, 2006).

Considering the transnational nature of these threats, the operationalization of conflict prevention has been quite challenging, especially in societies coming out of conflict and for communities that are impoverished and incapacitated to deal with conflict risk factors. The transnational nature of risk of conflict has led to increased cooperation between governments and social groups in taking action to institutionalize mechanisms for conflict prevention. However, the practice of conflict prevention has not been conceptualized within the prism of institutionalization and in the context of regional subsystem as a whole.

In this regard, there is a need for research work that presents a holistic conceptualization of conflict prevention that recognizes the cooperative interaction among multiple actors. This conceptual gap between theory and recent practices needs further exploration, which is part of the purpose of this study. For clarity, the term 'regional subsystem' refers to geographical zone of cooperation and interaction within a given sub-region in Africa (Anda, 2000). This paper focuses on the subsystem of West Africa and is used as an exploratory case study to reconceptualize recent development in the practice of conflict prevention through the lens of institutionalization.

\section{Rationale (Why West Africa)}

The sub-region of West Africa is widely considered to be one of the worst affected regions in Africa from the consequences of the end of the Cold War with specific reference to peace, stability, governance and development placing it 'amongst the world's most unstable regions'. The deficiencies in the political, social and economic spaces of communities represent existential risk factors that have the potential to generate conflict. The sources and causes of conflict in the sub-region have emerged from identity (ethnic, religion, nationalism), resources (economic agendas) and patrimonial politics (Francis, 2001, 2006). In some instances natural resources have served as a motiva- 
tion that fuel violence and prolonged conflict, and at some point built into sub-regional conflict complexes.

Therefore, conflict prevention processes in the sub-region are broad and continue to evolve bringing on board different methods of responding to potential crises and insecurities. Many studies have been conducted to understand the dynamics of conflict prevention in West Africa based on Economic Community of West Africa States (ECOWAS) peace and security architecture, on peacekeeping and humanitarian intervention, security sector reforms, elections and good governance, mediation, countering violent extremism, control of small arms and light weapon; all of which form parts of the processes for conflict prevention These studies have been undertaken by academics, researchers, including peace-building institutions across the sub-region and beyond. However, the wide range of practices of conflict prevention seems elusive. This makes its application sometimes lukewarm or understood at surface level and less appreciated.

However, the new framework for conflict prevention in West Africa requires actions to be taken in a cooperative way and in an institutional manner. Therefore, in this paper, I proposed the concept of 'Cooperative Institutionalization in Regional subsystem' as an analytical framework to re-conceptualize institutional cooperation for conflict prevention between and amongst regional organizations, state government, transnational civil society structures as well as sub-state level processes. However, in order to give my conceptual postulation clarity, I will briefly explain three critical issues why West Africa is used to test its validity and applicability as a method or process for conflict prevention in regional subsystems.

\section{Regional Conflict Formation}

The term Regional Conflict Formation (RCF) was initially used in the 1980s to understand the development of regional sub-systems in the study of international relations, security studies, regional integration and regional security complex during the Cold War (Buzan, 1991). However, the connection between RCF approach and regional security complex initially focused on a conceptual understanding of the governance and management of inter-state security within regions as a result of the Cold War rivalries and did not concentrate on contemporary internal conflict issues. However, in recent years, the concept of RCF is used to describe the 'regional character of conflict' and the 'complex web of cause and effect that is difficult to understand or address at the level of a single state' (Buzan, 1991). This means that sub-regions that are interlinked by a common history, politics and socio-economic processes are met with common vulnerabilities with spillover effect across borders (Vayrynen, 1984).

West Africa is widely considered to be quite unstable as various countries have been 'embroiled in an interconnected web of conflicts' that destabilized the entire sub-region, creating more weak states that have the potential to collapse or with visible character- 
istics of politically disintegrating and socio-economically degenerating into crisis point (Rotberg, 2008). This transnational nature of the conflict is characterized as RCF and serves as the rationale for cooperative institutionalization of prevention mechanisms as a regional approach to respond to risk factors in West Africa. This is premised on the arrangement of partnership between ECOWAS, state governments, transnational civil society networks and local institutions that cooperate towards the institutionalization of policies and programs across communities and institutions to prevent conflict (KAIPTC, 2010).

\section{West Africa Conflict Prevention Framework:}

\section{ECOWAS Conflict Prevention Framework (ECPF)}

In 2007, the ECOWAS secretariat was transformed into a Commission with a new vision to build architecture for Peace and Security. Part of this vision is the basis for the adoption of the ECOWAS Conflict Prevention Framework (ECPF) in 2008 as a roadmap for conflict prevention (ECOWAS, 2008). However, this framework requires conflict prevention mechanisms to be integrated across member states. The Framework, by all intent and purpose is well structured, as it intends to engineer the implementation of many different sets of activities that will directly or indirectly impact on the prevention of conflict and promote human security. The framework intends to make conflict prevention programs well harmonized and coordinated with both state and non-state actors implementing activities that are guided by the principles of the framework. The operationalization of the ECPF hinges on cooperation across wide-range of institutions, thereby giving relevance to the conceptual application of cooperative institutionalization of conflict prevention mechanisms in West Africa (Ismail, 2011).

\section{National Infrastructures for Peace (NI4P)}

The internal dynamics across countries in the sub-region paint a grim reality of inherent risk factors for conflict. This has encouraged many countries, especially those in conflict or coming out of conflict to develop national and local structures for peace. These structures form pathways to developing infrastructure for peace in the state. Country-level I4P brings together national and local institutions or groups to find common grounds to conflict issues in their communities (Tongeren, 2011).

In this regard, NI4P composes of other activities such as early warning systems, community mediations and dialogue, peace negotiations, security protection, local police partnership, etc. It also involves institutions such as government ministries, departments and agencies in the form of human right commission, office of the Ombudsman, state security forces, civil society organizations, religious institutions, traditional groups and community based organizations; all of which form an interconnected web of institutions that cooperate and take action to mitigate risk factors to conflict within the state. 


\section{Institutionalization/Collective Prevention Nexus in Regional Subsystem}

For a conflict prevention mechanism to work in regional sub-system, they should be institutionalized. They gain strength and viability when they are objectively infused into institutions. In such, an institutionalized framework serves as pillars that uphold collective actions, which become routinized in the social, economic and governance system of communities. This enforces conformity and performance of duties among actors and across sectors (Scott, 1995, p. 33, 2014). In the context of collective action for conflict prevention, institutionalizing methodically infuses into organizational structures, response mechanisms to prevent conflict (Lund, 1996, p. 176). In a sub-regional framework, institutions are instrumental elements for collective action to prevent conflict across communities (Lund, 2008).

West Africa is overshadowed by an array of risk factors as a result of weak institutions, the crisis of governance and economic challenges. In this regard, peace-building institutions are partnering on issues of early warning, security governance, cross border security and countering violent extremism. Their partnership has brought about a network of cooperation amongst institutions at various levels. Therefore, this paper proposes a conceptual approach as part of the discourse on how, why and in what way institutional cooperation responds to risk factors from local, national to regional subsystem level in West Africa.

\section{Conceptualizing Cooperative Institutionalization in Regional Subsystems}

As a general term, cooperation is defined as a process of working together to achieve a common end. It involves collaboration, partnership, mutual support, coordination, joint action, combined effort, synergy, compromise, etc. Cooperation in this current discourse stems from the liberal ideas of institutional interaction, dialogue and decision-making for progress and change in society. However, it takes a departure from the traditional approach of inter-state engagement and focuses on cooperation amongst a collective group of state and non-state actors.

The organization of transnational cooperation is increasingly taking place at various levels and with multiple actors across international and regional sub-systems. This means that interactions between states and non-state actors form part of the broader network of cooperation. These networks of interaction amongst multiple institutions is what I described as 'Cooperative Institutionalization in Regional Subsystem'.

In my view, cooperative institutionalization in a regional subsystem describes a network of formal and informal processes of collective action and decision-making amongst multiple institutions towards achieving their collective interest in the subsystem. These institutions vary in type, level of operation, constitutive organs and socially constructed setting, but form part of a growing set of institutions that collectively engage, inter- 
act, implement and coordinate in taking action to institutionalized ideas, principles, norms, rules, laws, policy initiatives, etc. Such institutions within a regional subsystem include intergovernmental bodies, state-governments and their departments and agencies, transnational organizations, non-state actors, multilateral agencies, regional civil society structures and sub-state groups at national and local levels. They all make up the institutional pillars, which persist over time, forming a geographic zone of cooperation.

It is important to note that the State is the core pillar that holds the foundation for cooperation across all levels and forges the interconnected web of relationships amongst institutions in the sub-system. A categorization of these institutions is made in the table below.

Table 1: Types of Institutions in the Regional Subsystem

\begin{tabular}{lll}
\hline \multicolumn{1}{c}{ Regional Institutions } & \multicolumn{1}{c}{ State Institutions } & Non-State Institutions \\
\hline -Regional Inter-governmental & -Federal and State Governments & - Civil society groups \\
Organizations & (Executive, Legislature, Judiciary) & - Non-governmental \\
-Inter-state Arrangements & -Departments & Organizations \\
-Transnational Cooperation & -Government Agencies and Corpo- & - Interest groups \\
-Regional Civil Society groups & rations, military commissions and & -Academia \\
-Interest-based regional & Police sector, etc. & - Community-based \\
organizations, etc. & & organizations \\
& & -Religious institutions \\
& & -Traditional institutions \\
\hline
\end{tabular}

Cooperative institutionalization, in practice, recognized that within the scope of regional sub-systems institutional interaction could be structurally symmetric or asymmetrical. There are different patterns of interactions that produced cooperation. This means there are institutions with unequal status, power, influence, depth and scope, whilst there are others with relatively equal standing, authority and operational scope. This heterogeneous nature of the interaction is important for the formation of an institutional order that strives for cooperation.

Standing with an institutionalist appeal, cooperative institutionalization in the regional sub-system finds its root from historical and sociological institutionalism. In hindsight, historical institutionalism is associated with rules, norms and regulations promulgated by formal and informal institutions as well as 'emphasize the asymmetries of power associated with the operation and development of institutions' (Hall \& Taylor, 1996, Simmons \& Martin, 2002). Sociological institutionalism also emphasizes that formal rules, procedures, norms, symbolic systems, cultural-cognitive frames are socially constructed and transmitted by cultural practices for the realization of institutional order. These historical and social commonalities amongst governments and people form the basis for cooperation as an institutional practice, and, in theory, as cooperative institu- 
tionalization. Furthermore, cooperative institutionalization in the regional subsystem is realized when institutions converge to make or take collective decision. This point of convergence serves as a central point for cooperation that enables collective actions, conformity to rules and policies as well as implementation of programs to achieve their common end. Institutionalization of ideas, programs, norms, rules, and laws in a subsystem are realized when institutions converge and translate their ideas into implementable goals.

For the purpose of this study, the regional subsystem is described as an organized constitutive component of political, economic, social and even cultural systems of interaction within a given community of nations distinctive to or from the larger international system. Interactions, in this case, are made possible as a result of geographical proximity bounded by mutual structures of cooperation in the economic, political and socio-cultural life of the constituting states and her peoples. Thereby, forming an interconnected web of relationship that endures internal acceptance and recognized within its external environment. However, regional subsystems are liable to change as a result of internal structural dynamics and external pressures; and 'changes in one part of the subsystem can become the catalyst for change in other parts of the region' (Thompson, 1973).

\section{Pre-conditions for Cooperative Institutionalization in Regional Sub-system}

In a regional sub-system, careful observation of interactions unfolding amongst the multiple categories of institutions shows that there are preconditions in the social systems for cooperation to be realized. They are highlighted and explained below.

\section{Commitment Capacity and Domestication of Commitment}

For any cooperative venture to be pursued and gain effect in a social system, all participants, be they individuals, groups and institutions must exert an unquestionable degree of commitment. In regional sub-systems, cooperative institutionalization is applicable to the condition that there is an unflinching commitment agreed upon by all institutions involved. Without commitment by all participating institutions it is hard for the instrumental pillars, carriers and drivers in the cooperation process to gain meaning and get an outcome that resonates with the common interest of them all.

States-governments are key players in the establishment of commitment and the political capital and willingness rest on them for its realization. When states in a regional subsystem make a commitment to a particular process of cooperation, its institutions and agencies become involved in the process, and non-state actors and other partners are given a voice. This enables collective action that leads to a process of institutionalization. 


\section{Mobilization Capacity}

Mobilization here means bringing resources to bear in responding to a given issue. It can involve both physical and non-physical as well as political, economic, financial, social and other technical and human resources. It also implies the ability of the regional sub-system itself, having the capacity to reach out and garner support from the multiple sets of state and non-state institutions that are required in the implementation of a cooperative agenda. In the regional process of integration, there are states that have hegemonic status and others that are small. In this case the hegemonic state must have the rallying power to bring all others into the ideology of cooperation. Also, non-state actors are recognized as having supplementary role in the institutionalization of the regional cooperative agenda.

\section{Vertical and Horizontal Partnership}

Partnership implies the establishment of relationship between two or more entities that are characterized by mutual cooperation and responsibility. There must be partnership between and amongst institutions. Vertical and horizontal partnership, in this case, connotes interaction between regional institutions and government of member states including non-state and local actors. This structure of partnership helps institution to coordinate and complement one another as they deal with social concerns.

\section{Harmonization of Policies and Programs}

Regional sub-systems at any given point in their history can develop structures for formal integration of economic and social policies as well as security cooperation. In this case, the system requires states to have common policies to achieve their common ends. This requires harmonization of policies and programs amongst member states, and participating institutions. It also means that programs and policies are designed and implemented across all states and institutions. Realizing the harmonization of normative frameworks from sub-regional institutions into the national legislation of member states is a crucial aspect towards achieving the objectives of the process of institutionalization. In this regard, crucial to the adoption of norms is the need to adopt them into laws in the national legislative structures of the various states that have signed and ratified them.

\section{Multi-Dimensional Actors}

Cooperative institutionalization is based on the assumption that many institutions are involved. The process of cooperation must be very inclusive of a variety of groups and institutions that are involved in taking collective action for a common end. As noted by Leatherman, 'multilateral endeavors provide an opportunity to admit new actors, giving 
legitimacy to the parties, reframe the issues, establish mutually agreed rules' as well as provide a system of participation of civil society actors (Leatherman 1993, p. 405).

\section{Cooperative Institutionalization of Conflict Prevention Mechanisms in Regional Subsystem}

Cooperative institutionalization conceptualizes the process of conflict prevention, and especially in the organization of preventive regimes in regional conflict complexes in Africa. Its purpose is to understand the network of interactions among and between institutions as well as methods, programs, policies and activities in the implementation of regional conflict prevention programs. Institutional cooperation is identified as a core variable that gives meaning to the concept. It is the enabler of interaction and the foundation for the convergence of different state and non-state actors in finding solutions to conflict and human security challenges.

These actors include regional organizations, state governments, transnational groups, local governments, specialized agencies, interest groups, and varieties of civil society structures. Together, they form an interconnected network of institutions working on policies, implementing activities, collaborating and coordinating on different issues in the prevention of violence and conflicts within local communities, at the state level, and between states in a regional subsystem. Some have equal status, power and authority whilst others do not. There is some level of hierarchy in their interactions from the regional, to state government and local structures. But all of them can be resourceful and actively work on issues that help prevent conflict in their communities, states and sub-regions.

Institutions are important for conflict management and prevention. This is because, they frame norms, rules and regulative processes as well as create the platform for cooperation in collective decision-making and constraining actors in ways that regulate, manage or even avert conflict. Alexander Siedschlag states that the theory of institutions as a platform for 'optimal collective decision making' aims to prevent conflict right from their inception. In drawing up a conceptual analysis of political institutionalization and conflict management in Europe, he uses a reflective institutionalization framework as his approach to a rationalist design for understanding institutionalization process towards conflict management. In his view, the concept of reflective institutionalization aims at a deep transformation of conflict, ameliorating the underlying culture of conflict through proactive or preventive conflict management (Siedschlag, 2001, p. 10).

In a regionalization framework, institutions are essential for the implementation of programs to prevent conflict in communities. Conflict risk factors have led to cooperation between organizations for political and security purposes. Institutionalizing these cooperative arrangements are critical for their successful implementation of response mechanisms to reduce the risk of conflict. Many regional organizations have taken 
responsibility to find solutions through peacemaking, peacekeeping and other forms of political intervention. Laying a foundation for the prevention of conflict within the regional subsystems. Therefore, cooperative institutionalization conceptualizes these approaches to respond to risk of conflicts in West Africa.

Building a preventive regime in a regional subsystem requires collective action. However, collective action by all actors is only possible when there is a platform for interaction that enables cooperation. The convergence of state and non-state institutions on initiatives such as early warning systems, infrastructures for peace, preventive diplomacy, restorative justice systems, social empowerment and development projects enables them to take or make collective decisions, identified methods of implementation and decide on the collectiveness of their endeavors towards conflict prevention.

\section{Cooperative Institutionalization of Conflict Prevention Mechanisms: From Concept to Practice in Africa}

The AU Peace and Security Council (PSC) was conceived from the desire of the AU to reform the OAU MCPMR and has become the foundation for the African Peace and Security Architecture (APSA). The PSC was adopted in July 2002, entered into force in December 2003 and started operations in March 2004. It is 'a collective security and early-warning arrangement to facilitate timely and efficient response to conflict and crisis situations in Africa' (Africa Union Commission, 2002). The PSC focuses on the 'promotion of peace, security and stability in Africa; anticipating and preventing conflicts; promoting and implementing peacebuilding and post-conflict reconstruction activities as well as coordinate and harmonize continental and regional efforts for institutional cooperation in prevention of conflicts. Membership into the council is on the basis of 'equitable regional representation and rotation' across the various regional subsystems in Africa. The decisions of the Council are generally guided by the principle of consensus' and in cases where they are unable to reach a consensus to take a decision, a simple two-third majority vote can take effect (William, 2011, p. 158, Biswaro, 2013).

The core of the AU architecture for peace is the PSC, which was developed with operational pillars serving as essential response structures to deal with conflicts and insecurities. They include the Continental Early Warning System (CEWS), the African Standby Force (ASF), the Panel of the Wise and the Peace Fund (African Union, 2001). There is a process of cooperative institutionalization of these continental frameworks in regional subsystems through existing Regional Economic Communities (REC) and their Regional Mechanism for Conflict Prevention, Management and Resolution. For example, CEWS has been institutionalized into East Africa community through IGAD's Conflict Early Warning and Response Mechanism; the same has been done in the West African Community with the ECOWAS Early Warning and Response Network and Southern Africa has also institutionalized early warning through SADC's Regional Early Warning 
Centre based in Gaborone, Botswana. This method of cooperative institutionalization of conflict prevention has been applied in the implementation of the Africa Standby Force to undertake peace support operations and Panel of the Wise to undertake mediation and negotiation processes in different regional subsystems in Africa.

These structures have been used to respond to conflict and crisis situations in different countries. They have shaped AU response and enabled harmonization and coordination of activities in the Commission's various interventions to crisis situations across various regional subsystems as well as arrangement of cooperation with external partners and non-state actors such as regional and national civil society structures. Since 2015, the AU has developed an operational roadmap of APSA from 2016 to 2020 focusing on the link between development and conflict prevention. Also, in 2015, 'the AU endorsed its Conflict Prevention Framework as a Continental Structural Conflict Prevention Framework (CSCPF) as well as country structural vulnerability assessment (CSVAs).

During the AU summit in January 2017, the AU Master Roadmap on Practical steps for silencing the guns by 2020 was adopted. This roadmap maintains that national and regional structures must develop 'practical output in relation to structural prevention, including infrastructures for peace and structural vulnerability assessment (SVAs) (Carvalho 2017, p. 5). The AU designed and operates institutional frameworks at a continental level. However, states and regional structures have a greater role to tackle risk and vulnerabilities to conflicts. Structural problems need to be recognized and infrastructures for peace need to form part of the regional and country-level response to prevent conflict.

\section{The Case of West Africa}

From an analytical point of view, the evolving preventive regime in West Africa emphasizes the need for conflict prevention processes to be integrated across countries and institutions. However, this approach to conflict prevention can only be made possible on the basis that different sets of institutions undertake activities within their area of engagement that may impact on the prevention of conflict at local, national and across countries. ECOWAS normative instruments now recognize the inextricable link between economic development and regional integration and the need for security of the people of West Africa through the institutionalization of conflict management systems and structures. Though the priority for integration in the sub-region was for economic cooperation and harmonization of economic agenda of member states, there is now a new vision of 'integration with emphasis on prevention' in order to achieve the collective action needed amongst member states for conflict prevention. This emphasis sits well with systematic prevention of conflict based on regional approach to address security threats. 
The new approach to prevent conflict emphasis that normative instruments should be implemented through harmonization and domestication of response mechanisms across member states. This is the logical argument for cooperative institutionalization of conflict prevention. For example, through the ECOWAS Small Arms Commission Programme (ECOSAP), legal frameworks have now been enacted to prevent the flow of weapons, a regional code of conduct for the Armed forces and Security services and a Regional Framework for Security Sector Reforms and governance have been harmonized and political support being galvanized for these principles to be integrated and institutionalized by states government. This will go a long way towards governance and control of armed forces in the sub-region. In addition, ECOWAS Counter-Terrorism Strategy and Implementation Plan has been rolled out for member states to integrate into their national security strategy.

This new approach for collective prevention presents a vertical and horizontal method to institutionalize conflict prevention agendas within ECOWAS and its specialized institutions as well as between ECOWAS Commission, member states, non-state actors and even the private sector. This means that the ECOWAS Commission has a responsibility to harmonize its conflict prevention agenda across departments and agencies within the Commission in order to achieve the gains of collective prevention. For example, the ECOWAS Early Warning Programme (ECOWARN) should be able to give information, early enough for the Department of Political Affairs to coordinate with the Council of the Wise in undertaking fact-finding mission or mediation efforts in a member state facing threats of instability. All these networks of interaction amongst different institutions are conceptualized as cooperative institutionalization of conflict prevention mechanisms.

As seen in Table 2 below, conflict prevention in West Africa requires a multi-actor approach involving different sets of institutions. There are four institutional methods prescribed in the table below. Firstly, ECOWAS and its departmental and specialized unit design policies within the framework for conflict prevention and working under the auspices of the commission undertakes programs with impact across all member states. For example, in the aspect of Security Governance, the conflict prevention framework states that 'ECOWAS shall develop and promote the implementation and monitoring of a set of practical guidelines to govern the activities of all actors implementing or supporting SSR initiatives in the sub-region'. In this regard, a Code of Conduct was adopted by the ECOWAS Council of Ministers in August 2011 in order to 'promote the integration of democratic norms into the behavior of the armed forces and security services' within member states of ECOWAS (Uzoechina, 2014, p. 9)

Another institutional approach highlighted above is a partnership between ECOWAS and regional non-state actors. This method is identified based on the current pattern of engagement between ECOWAS and Non-State actors with regional focus. This approach gives due consideration to the fact that many non-state institutions work on training 
Table 2: Methods/Processes of Institutionalization of preventive action in West Africa

\begin{tabular}{|c|c|c|c|}
\hline Actors & $\begin{array}{c}\text { Method } \\
\text { of engagement }\end{array}$ & $\begin{array}{l}\text { Structure } \\
\text { of Activities }\end{array}$ & Current Initiatives \\
\hline \multirow{3}{*}{$\begin{array}{l}\text { Regional } \\
\text { State }\end{array}$} & $\begin{array}{l}\text { ECOWAS Sectoral/ } \\
\text { department unit }\end{array}$ & $\begin{array}{l}\text { Vertical and Horizontal } \\
\text { coordination with state } \\
\text { and non state actors } \\
\text { Designing and implementing } \\
\text { regional policies }\end{array}$ & $\begin{array}{l}\text { Department of Political Affairs, Peace } \\
\text { and Security on electoral governance } \\
\text { and monitoring, etc. } \\
\text { ECOWAS Parliament on } \\
\text { democratic governance } \\
\text { Early Warning Directorate on } \\
\text { regional early warning systems }\end{array}$ \\
\hline & $\begin{array}{l}\text { ECOWAS and Regional } \\
\text { Non-State Partnership }\end{array}$ & $\begin{array}{l}\text { Design and implementation } \\
\text { of Preventive Action } \\
\text { Country-based networks } \\
\text { and coordination }\end{array}$ & $\begin{array}{l}\text { ECOWAS/WANEP Partnership in } \\
\text { Implementation of Early Warning } \\
\text { across West Africa }\end{array}$ \\
\hline & $\begin{array}{l}\text { Intergovernmental } \\
\text { Specialized Agencies }\end{array}$ & $\begin{array}{l}\text { Inter-state cooperation } \\
\text { for preventive action } \\
\text { Design and implementing } \\
\text { regional policies }\end{array}$ & $\begin{array}{l}\text { West Africa Police Chiefs Committee } \\
\text { on Security Policing and transnational } \\
\text { criminal enterprises }\end{array}$ \\
\hline Non-State & $\begin{array}{l}\text { Transnational NGOs } \\
\text { Regional Civil Society }\end{array}$ & $\begin{array}{l}\text { Training, and research, } \\
\text { capacity building efforts, } \\
\text { advocacy, awareness-raising, } \\
\text { etc. }\end{array}$ & $\begin{array}{l}\text { WANEP, WACSOF, WASSN, WAANSA, } \\
\text { etc. undertakes program on Early warning, } \\
\text { Training and research, Security govern- } \\
\text { ance and Small Arms Control respectively }\end{array}$ \\
\hline $\begin{array}{l}\text { Local } \\
\text { Actors }\end{array}$ & $\begin{array}{l}\text { Traditional/ } \\
\text { local institutions }\end{array}$ & $\begin{array}{l}\text { Community building, } \\
\text { restorative justice, } \\
\text { security cooperation }\end{array}$ & $\begin{array}{l}\text { National Infrastructures for Peace (NI4P), } \\
\text { Local policing boards, community healing } \\
\text { and reconciliation, etc. }\end{array}$ \\
\hline
\end{tabular}

and research, capacity building programs, policy advocacy with some level of coordination with country-based network and local actors. For example, ECOWAS and West Africa Network for Peace Building, has built more than a decade long partnership in the development of early warning systems in West Africa.

In addition, intergovernmental arrangements among specialized agencies has an important role to play in making sure that conventions, treaties, laws and policies coming from regional grouping, are harmonized and implemented in the state. Those institutional organs of government whose programs fall within the scope of regional initiatives must take appropriate action towards the implementation of such policies. The West Africa Police Chiefs Committee operates within an intergovernmental framework in dealing with regional security challenges such as transnational criminal enterprises, security policing, etc. 
Sub-national and local institutions such as traditional authorities and religious groups and civil society groups take on initiatives towards creation of national and local infrastructures for peace as we see in Ghana, local police partnership board as developed in Sierra Leone, community healing and reconciliation programs as developed by religious and civil society groups in northern Nigeria.

All the actors grouped in the table above can play a variety of roles and undertake activities for conflict prevention ranging from early warning, preventive diplomacy, mediation, negotiation, fact-finding, outreach, peacemaking, election monitoring, security governance, cross-border security, local peace committees, etc.

Therefore, conflict prevention frameworks are no longer state-centered alone as the new theatre of violence and insecurity comes from within states and regional subsystems with communities imploding on one another and creating a state of instability and conflict that affects entire sub-regions (Tschirgi, 2012; Wallensteen, 2015). In the case of West Africa, ending such conflicts requires the involvement of multiple working together to pre-empt and prevent conflict (Ramsbotham, Woodhouse, \& Mail, 2011).

\section{Conceptual Flaws}

Cooperative institutionalization conceptualizes relational arrangement, partnership, collaboration, coordination and interaction between different institutions in a regional sub-system. However, the process of cooperation takes time and its outcome may be hard to evaluate. The impact and outcome of collective action, shared the responsibility or intersubjective interactions spanning varieties of institutions are difficult to assess in a regional sub-system. Institutional and state politics, interests of groups and unforeseen circumstances also make it hard to evaluate their effect in the subsystem.

Furthermore, institutions in a different point in their history can change. This means they can change their goals, interest and focus in response to exogenous or endogenous forces. These changes affect institutional performance, conformity to rules, norms, and value systems. It also affects existing interactions and collective actions between institutions as interests change, making it difficult or impossible for cooperation to thrive within an already organized institutional order. Therefore, the concept can be constrained by structural changes in response to changes in interest and direction of an institution.

Another fault line to consider is the issue of political commitment. The key institutional actor for cooperative institutionalization in a regional sub-system is the state. The State connects the regional structure to national and local institutions and creates a stable governance system with the necessary institutions. Therefore state-governments need to be politically committed to a process of cooperative institutionalization through agreed-upon rules, convention, regulations, laws and policies that must be transmitted 
into national and local laws and policies. The collective actions of states to cooperate and institutionalize norms and rules across a regional sub-system are important and its lack thereof challenges the very foundation of the theoretical assumptions and causal logic of this work.

\section{Conclusion}

Theorizing or conceptualizing in social sciences research is a bit of a complex process of arranging ideas, facts and observable phenomenon in our social environment as the basis of forming a theoretical proposition. As mentioned by Grix (2004) 'theory is an abstraction of reality, in which concepts-with referents in the real world- are related to other concepts, offering us tentative hypothesis or explanation'. This paper proposes that cooperative institutionalization is a method for collective action towards conflict prevention in regional subsystems. As the global community is becoming more arranged in regional subsystem, especially in developing regions like Africa, there is the need for a conceptual framework that analyzes institutional cooperation beyond the confines of the state. These interactions take place vertically and horizontally within states and between states and are becoming viable in dealing with human security challenges.

This article attempts to put into perspective the practice of cooperative institutionalization of conflict prevention mechanisms in West Africa. As conceptualized in the paper, cooperative institutionalization maintains that culture, shared history, common interest has enabled intersubjective interaction within subsystems leading to the establishment of regional integration programs and transnational networks of cooperation amongst different institutions. In the context of conflict prevention, cooperative institutionalization applies to the formation of norms and policies and their implementation by different institutions within the subsystem. In Africa, there are Regional Economic Communities that foster cooperation amongst countries in dealing with matters of interest to them.

Such matters may include transnational criminal activities, the control and proliferation of illicit flow of small arms and light weapons, transnational terrorism, drug trafficking, environmental concerns, etc. As stated in the UN Secretary-General Progress Report on the Prevention of Armed Conflict, these human security risks that affect multiple countries across continents and regional subsystems can only be reduced through a process of 'systematic prevention'. In West Africa, the ECOWAS Conflict prevention framework alludes to this approach, as it requires a systematic process of implementation of conflict prevention programs through cooperation amongst different organizations and groups.

Cooperative institutionalization in a regional subsystem is realized on the basis of collective action and shared responsibility giving legitimacy to decision making and rules that are enforced by multiple actors for conformity and adherence towards achieving their common collective ends within the subsystem. However, it is important to note that lack of commitment by state-governments, the domestication of decisions and 
rules as agreed by states and the inability of non-state actors to engage renders the concept less applicable.

\section{References}

1. African Union (2001). Constitutive Act of the African Union, Addis Ababa: AU.

2. African Union Commission (2002). Protocol Relating to the Establishment of the Peace and Security Council of the African Union. Addis Ababa: AU.

3. Anda, O. M. (2000). International Relations in Contemporary Africa. Lanham: University Press of America.

4. Biswaro, J. M. (2013). The Role of Regional Integration in Conflict Prevention, Management and Resolution in Africa: The Case of African Union. Brasília: Fundacao Alexandre de Gusmao.

5. Buzan, B. (1991). People, States, and Fear: An Agenda for International Security Studies in the Post-Cold War Era ( $2^{\text {nd }}$ ed.). New York: Harvester Wheatsheaf.

6. Carvalho, de G. (2017). Conflict Prevention: What's in it for the AU. Policy Brief, Pretoria: Institute for Security Studies.

7. ECOWAS (2008). ECOWAS Conflict Prevention Framework. Regulation MSC/ REG.1/01/08. Abuja: Mediation and Security Council, ECOWAS Commission.

8. Francis D. (2006). Uniting Africa: Building Regional Peace and Security Systems, London: Ashgate.

9. Francis, D. (2001). The Politics of Economic Regionalism: Sierra Leone in ECOWAS. London: Ashgate.

10. Grix, J. (2004). The Foundations of Research. London: Palgrave Macmillan Publishing.

11. Hall, P., \& Taylor, R. (1996). Political Science and the Three New Institutionalisms. Political Studies, XLIV, 936-957.

12. Ismail, O. (2011). ECOWAS and Human Security. In T. Jaye and S. Amadi (Eds.), ECOWAS and the Dynamics of Conflict and Peacebuilding (pp. 206-227). Dakar: CODESRIA.

13. KAIPTC Workshop Report (2010). Enhancing the Operationalization of the ECOWAS Conflict Prevention Framework. Accra: KAIPTC.

14. Leatherman, J. (1993). Conflict Transformation in the CSCE: Learning and Institutionalization. Cooperation and Conflict, 28(4), 403-431.

15. Lund, M. (1996). Preventing Violent Conflict: A Strategy for Preventive Diplomacy. Washington: United States Institute of Peace.

16. Lund, M. (2008). Conflict Prevention: Theory in Pursuit of Policy and Practice. In J. Bercovitch, V. Kremenyuk and W. Zartman (Eds.), The Sage Handbook of Conflict Resolution (pp. 287-321). Thousand Oaks: Sage.

17. Ramsbotham, O., Woodhouse, T., \& Mail, H. (2011). Contemporary Conflict Resolution ( $3^{\text {rd }}$ Edition). Cambridge: Polity Press.

18. Rotberg, R. (2008). The Failure and Collapse of Nations: States Breakdown, Prevention and Repair. In R. Rotberg (Ed.), When States Fail (pp. 1-4). Princeton: Princeton University Press. 
19. Scott, W. R. (1995). Institutions and Organizations. Foundation for Organizational Sciences. Thousand Oaks: Sage.

20. Scott, R. W. (2014). Institutions and Organizations: Ideas, interests and identities. Thousand Oaks: Sage.

21. Siedschlag, A. (2001), Political Institutionalization and Conflict Management in the New Europe-Path-Shaping for the Better or Worse? APSA Paper Presentation, September 30-August 2, San Francisco, U.S.A.

22. Simmons, B., \& Martin, L. (2002), International Organizations and Institutions. In In W. Carlsnaes, T. Risse and B. Simmons (Eds.), Handbook of International Relations (pp. 192-211). Thousand Oaks: Sage.

23. Thompson, W. R. (1973). The Regional Subsystem: A Conceptual Explication and a Propositional Inventory. International Studies Quarterly, 17(1), 89-117.

24. Tongeren, P. (2011). Increasing interest in infrastructure for Peace. Journal of Conflictology, 2, 45-55.

25. Tschirgi, N. (2012). Making the case for a Regional Approach to Peace building. Journal of Peace Building and Development. London: Routledge.

26. United Nations (2001). Report of the Secretary General on the Prevention of Armed Conflict, A/55/985-S/2001/574. New York: UN.

27. United Nations (2005). A More Secured World: Our Shared Responsibility, Report on U.N. Secretary General High Level-Panel on Threats Challenges and Change. New York: UN.

28. United Nations (2006). Report of the Secretary General on the Prevention of Armed Conflict, A/60/891. New York: UN.

29. Uzoechina, O. (2014). Security Sector Reforms and Governance Processes in West Africa: From Concept to Reality. Policy Paper. Geneva: Centre for the Democratic Control of Armed Forces (DCAF).

30. Vayrynen, R. (1984). Regional Conflict Formation: An Intractable Problem of International Relations. Journal of Peace Research, 21(4), 337-359.

31. Wallensteen, P. (2015). Understanding Conflict Resolution. London: Sage.

32. Williams, P. D. (2011). War and Conflict in Africa. Cambridge: Polity Press. 